\title{
Depressed, not depressed or unsure: Prevalence and the relation to well-being across sectors in South Africa
}

\author{
Authors: \\ Christa Welthagen ${ }^{1}$ \\ Crizelle Els ${ }^{1}$ \\ Affiliations: \\ ${ }^{1}$ WorkWell: Research Unit for \\ Economic and Management \\ Sciences, North-West \\ University, South Africa \\ Correspondence to: \\ Crizelle Els \\ Email: \\ crizelle.els@nwu.ac.za \\ Postal address: \\ North-West University, \\ WorkWell Research Unit, \\ Internal Box 202, Private Bag \\ X6001, Potchefstroom 2520, \\ South Africa \\ Dates: \\ Received: 17 May 2011 \\ Accepted: 10 July 2012 \\ Published: 27 Sept. 2012 \\ How to cite this article: \\ Welthagen, C., \& Els, C. \\ (2012). Depressed, not \\ depressed or unsure: \\ Prevalence and the relation \\ to well-being across sectors \\ in South Africa. SA Journal \\ of Industrial Psychology/SA \\ Tydskrif vir Bedryfsielkunde, \\ 38(1), Art. \#984, 12 pages. \\ http://dx.doi.org/10.4102/ \\ sajip.v38i1.984 \\ Note: \\ The authors would like \\ to express their sincere \\ gratitude to Afriforte (Pty) \\ Ltd for the use of their data \\ and the assistance with the \\ statistical analyses.
}

(C) 2012. The Authors. Licensee: AOSIS OpenJournals. This work is licensed under the Creative Commons Attribution License.
Orientation: Work engagement, burnout and stress-related ill health levels of individuals, suffering from depression, who are unsure whether or not they suffer from depression, or who do not suffer from depression, have not been investigated in South Africa.

Research purpose: The main objectives of this study were to investigate the prevalence of depression amongst employees in South African organisations and the relationship of depression with specific well-being constructs.

Motivation for the study: Organisations should know about the prevalence of depression and the effects this could have on specific well-being constructs.

Research design, approach and method: A cross-sectional design was followed. The availability sample $(n=15664)$ included participants from diverse demographics. The South African Employee Health and Wellness Survey was followed to measure constructs.

Main findings: The results showed that $18.3 \%$ of the population currently receive treatment for depression, $16.7 \%$ are unsure whether or not they suffer from depression and $65 \%$ do not suffer from depression. Depression significantly affects the levels of work engagement, burnout and the occurrence of stress-related ill health symptoms.

Practical/managerial implications: This study makes organisations aware of the relationship between depression and employee work-related well-being. Proactive measures to promote the work-related well-being of employees, and to support employees suffering from depression, should be considered.

Contribution/value-add: This study provides insight into the prevalence of depression and well-being differences that exist between individuals, suffering from depression, who are unsure whether or not they suffer from depression, and who do not suffer from depression.

\section{Introduction}

Depression is one of the most debilitating, widespread and costly health problems worldwide and it is the most common mental health problem in the Western world (McIntyre \& O'Donovan, 2004). It affects approximately 340 million people worldwide and has a high prevalence in almost every society. Furthermore, the World Health Organisation (2000) predicts that by 2020, depression will be the second largest contributor to the global health burden.

Depression creates a huge economic burden for organisations and up to $69 \%$ of the costs brought about by depression can be described as indirect costs. Indirect costs are difficult to calculate and include lost productivity resulting from absenteeism, disability, premature mortality, and lost wages (Sullivan, 2005). Only 31\% of the costs are direct costs, which include hospitalisation, treatment by physicians, drugs, therapy and other medical expenses (Sullivan, 2005). The per capita annual cost of depression in organisations is significantly more than that of hypertension or back problems, and is comparable to that of diabetes or heart disease (Druss, Rosenheck \& Sledge, 2000). Greenberg, Kessler, Nells, Finkelstein and Berndt (1996) estimated that the workplace costs of depression were $\$ 51.5$ billion in 2000 in the United States. Depression-related absenteeism was estimated to account for $\$ 36.2$ billion of this total and depression-related presenteeism.

Apart from the huge economic burden that depression creates as well as the loss of labour it causes through both presenteeism and absenteeism, a number of researchers also indicated that depression affects an individual's work engagement levels, burnout levels and the occurrence of stress-related ill health symptoms (Demerouti, Bakker, Janssen \& Schaufeli, 2001; Fruede, Seibt, Pech \& Ullsperger, 2005; Schaufeli \& Bakker, 2004; Takai et al., 2009).

Employee work engagement is regarded as a vital driver of business success and competitive advantage. It is widely known that engaged employees have high levels of energy and are 
enthusiastic about their work (Schaufeli \& Bakker, 2004); moreover they are often fully immersed in their work, which causes the working day to seem faster to them (May, Gilson \& Harter, 2004). Engaged employees exercise influence over events that affect their lives and because of their positive attitude and high activity levels, they create their own positive feedback, in terms of appreciation, recognition, and success (Schaufeli et al., 2001). Furthermore, work engagement is directly linked to organisational outcomes affecting employee retention, productivity and loyalty whilst it is also a key link to customer satisfaction, company reputation and overall stakeholder value (Lockwood, 2007). According to Hakanen, Schaufeli, and Ahola (2008), work engagement and depression correlate negatively. It can therefore be expected that employees suffering from depression might experience lower work engagement levels.

Burnout is a negative work-related well-being state. Employees who suffer from burnout are exhausted, cynical and feel ineffective (Maslach, Schaufeli \& Leiter, 2001). Exhaustion interferes with effectiveness and it is difficult for an employee to gain a sense of accomplishment when he or she feels exhausted. Schaufeli, Taris and Van Rhenen (2008) established a definitive relationship between burnout and depression, implying that employees who experience depression might also experience burnout. The causal effect between burnout and depression is, however, unclear. Some studies have found that burnout predicts depression (Ahola et al., 2005; Toppinen-Tanner, Ahola, Koskinen \& Väänänen, 2009), whereas other studies found the reverse to be true (Maslach et al., 2001; Nyklíček \& Pop, 2005). Also, a study by Ahola and Hakanen (2007) has confirmed a reciprocal relationship between burnout and depressive symptoms.

Stress-related ill health, both physical and psychological, has many consequences, including absenteeism, loss of attentiveness and concentration and low energy levels (Rothmann \& Rothmann, 2006). Levinson and Druss (2005) found that individuals who suffer from depression seem more likely perceive themselves to be susceptible to physical illness. This implies that employees who suffer from depression may also suffer from other stress-related ill health symptoms as a result of their depression. Further research, especially in South Africa, is necessary to investigate how depression influences the characteristics of work-related well-being, such as work engagement, burnout and stressrelated ill health.

To conduct this study, one item in the South African Employee Health and Wellness Survey (SAEHWS) was followed to determine if a person suffers from depression (Rothmann \& Rothmann, 2006). This item differentiates participants into three groups:

- individuals who reported that they suffer from depression and who are currently receiving medical treatment for depression

- individuals who reported that they are unsure whether or not they suffer from depression (they may suspect that they are suffering from depressive symptoms but have not been medically treated for depression

- individuals who reported that they do not suffer from depression.

By comparing the three depression groups in terms of work engagement levels, burnout levels and the occurrence of stress-related ill health symptoms, a clear picture of the differences between the three groups will be obtained. The prevalence of depression in the study population will also be stated, indicating what percentage of the population suffer from depression and are currently being medically treated for depression; what percentage of the population are unsure whether they suffer from depression; and what percentage of the population do not suffer from depression.

The general objective of this research is to investigate the prevalence of depression in South African organisations and the relationship of depression with work engagement, burnout and stress-related ill health across different sectors in South Africa. The specific objectives of this research is to determine if work engagement, burnout, and stressrelated ill health levels differ amongst individuals across different sectors in South Africa (those who suffer from depression; those individuals who are uncertain whether or not they suffer from depression; and those who do not suffer from depression).

By gaining insight in the relationships between depression and various aspects of well-being, and into the prevalence of depression in a large population, organisations will be made aware of the influence of depression on an employee's vocational functioning. This study supports the notion that depression is a factor that cannot be ignored. Although there are a few existing studies on some of the aspects dealt with in this study, the concept of how work engagement levels, burnout levels and the occurrence of stress-related ill health symptoms differ amongst individuals who suffer from depression (and receive treatment), individuals who are uncertain whether they suffer from depression and those who do not suffer from depression, has not been researched yet. In particular, there are no studies using a population across different sectors in South Africa or studies using a large population group.

In the section to follow, a critical review of the literature is presented. This is followed by a discussion of the research method, which includes the characteristics of the participants, the measuring instrument, the research procedure and the statistical analysis. The results of the statistical analysis are then discussed, followed by the conclusions, limitations and recommendations.

\section{Synthesis and critical evaluation of the literature Depression and the prevalence thereof}

Depression can be characterised by a depressed mood, an inability to derive pleasure from things, weight loss or weight gain, insomnia or hypersomnia, psychomotor agitation, fatigue, feelings of insufficiency or guilt, indecisiveness 
or inability to concentrate, and thoughts about suicide (DSM-IV: American Psychiatric Association, 1994). These problems can become chronic or recurrent and can impair an individual's ability to cope with daily life to a large extent (World Health Organisation, 2010). Different types of depression include major depressive disorder (MDD), dysthymia, adjustment disorder, bipolar disorder and seasonal affective disorder (American Psychiatric Association, 1994; Williamson, 2008). Although each of these different types of depression has its own discerning symptoms, they also share a number of symptoms, such as changes in emotional states, changes in motivation, changes in functioning and motor behaviour and cognitive changes (Nevid, Spencer \& Greene, 2006).

For the purposes of this study, an individual who is receiving medical treatment for depression will be defined as an individual who suffers from depression. One item in the South African Employee Health and Wellness Survey (SAEHWS) was applied to determine if a individual suffers from depression (Rothmann \& Rothmann, 2006). This item divides participants into three groups:

- individuals who suffer from depression and who are currently receiving medical treatment for depression (depressed group)

- then there are individuals who are unsure whether or not they suffer from depression (unsure group)

- and lastly individuals who do not suffer from depression (not depressed group).

The DSM-IV categorises depression as a mood disorder, which includes, amongst other disorders, dysthymic disorder, major depressive disorder (MDD) and bipolar disorders (DSM-IV: American Psychiatric Association, 1994). Kessler et al. (2003) found that $16.2 \%$ of Americans aged 18 years and older had experienced MDD at some point in their lifetime, with $6.6 \%$ having had MDD in the past 12 months. The prevalence of depression varies to some extent across countries. The World Mental Health Consortium published 12-month prevalence rates for mood disorders in 15 countries (2004), but it is very difficult to compare the different rates across the 15 countries, because the countries vary in terms of the age range of subjects interviewed, the response rates and, most importantly, the diseases covered by the category 'mood disorder'. Three countries from the Americas participated:

- Colombia had a prevalence of mood disorders (MDD, dysthymia, and bipolar disorders) of $6.8 \%$

- Mexico $4.8 \%$ (with $6.6 \%$ having had MDD in the past 12 months)

- the US $9.6 \%$.

Seven countries in Europe conducted surveys, but only looked at MDD and dysthymia and did not assess bipolar disorder:

- Belgium had a prevalence of $6.2 \%$

- France $8.5 \%$

- Germany $3.6 \%$

- Italy $3.8 \%$
- the Netherlands $6.9 \%$

- Spain $4.9 \%$

- Ukraine $9.1 \%$.

The incidence in the Middle East and Africa was as follows:

- Lebanon had a prevalence of mood disorder (including bipolar disorders) of $6.6 \%$

- Nigeria had the lowest prevalence rate of $0.8 \%$.

In Asia the incidence was as follows:

- Japan had a prevalence of 3.1\%

- Beijing, China, had a prevalence of $2.5 \%$

- Shanghai, China, had a prevalence of $1.7 \%$.

An earlier WHO report, from the WHO International Consortium in Psychiatric Epidemiology (2000), reported the 12-month prevalence of mood disorders (MDD, dysthymia and bipolar) for Brazil to be $7.1 \%$, for Canada $4.9 \%$ and for Turkey $4.2 \%$.

In South Africa, information regarding the prevalence of depression is very limited and outdated (Tomlinson et al., 2009). However, a recent nationwide study conducted by Tomlinson et al. (2009) found that approximately $9.7 \%$ of the adult participants were diagnosed with MDD. Also, a recent study conducted by Stein et al. (2008) investigated the lifetime prevalence of psychiatric disorders in South Africa and found that $9.8 \%$ of the population suffered from MDD.

- Hypothesis 1: Depression is prevalent in South African organisations.

Depression has far reaching consequences and in this study we focused on the effect depression has on the work engagement levels of employees, the burnout levels and the occurrence of stress-related ill health symptoms.

\section{Work engagement and depression}

Work engagement may be described as a positive, fulfilling work-related state that can be characterised by vigour, dedication, and absorption (Schaufeli, Salanova, GonzálezRomá \& Bakker, 2002; Schaufeli \& Bakker, 2004). Vigour is characterised by high levels of energy and mental resilience whilst working, the willingness to invest effort in one's work, and persistence even in the face of difficulties (Schaufeli et al., 2002). Dedication refers to being strongly involved in one's work and experiencing a sense of significance, enthusiasm, and challenge (Schaufeli et al., 2002). Absorption is characterised by fully focussing on and being gladly engrossed in one's work, including the experience that time passes quickly and that one finds it difficult to detach oneself from work (Schaufeli \& Bakker, 2004).

The three-factor structure of work engagement - vigour, dedication and absorption - was confirmed in various international studies (Schaufeli et al., 2002; Schaufeli, Bakker \& Salanova, 2006). Although the three-factor structure was also confirmed in a South African study (Barkhuizen \& Rothmann, 2006), another study reported that the internal consistency of absorption was not acceptable (Naudé \& Rothmann, 2004). This is consistent with arguments that 
vigour and dedication can be considered the core constructs of work engagement (Schaufeli \& Bakker, 2001; Schaufeli et al., 2002). Therefore, various studies excluded absorption as a construct of work engagement (González-Romá, Schaufeli, Bakker \& Lloret, 2006; Montgomery, Peeters, Schaufeli \& Den Ouden, 2003). Based on findings in early work engagement research in South Africa, a two factor structure consisting of vigour and dedication was hypothesised and confirmed in various studies (Coetzer \& Rothmann, 2007; Jackson, Rothmann \& Van der Vijver, 2006; Rothmann \& Jorgensen, 2007; Rothmann \& Pieterse, 2007). This study therefore viewed work engagement as a two-factor structure consisting of vigour and dedication.

Engaged employees have high levels of energy, are passionate about their work, and are often fully engrossed in their job and, thus, they experience that time passes quickly (Macey \& Schneider, 2008; May et al., 2004). According to Bakker (2009), there are four reasons why engaged workers perform better than workers that are not engaged:

- engaged employees often experience positive emotions, including happiness, joy and enthusiasm

- they also experience better psychological and physical health

- they create their own job and personal resources (e.g. support from others)

- they transfer their work engagement to others.

The significance of work engagement is that it has constructive and positive consequences for the organisation. Research on work engagement reports that high levels of work engagement leads to:

- enhanced organisational commitment

- increased job satisfaction

- lower employee absenteeism and turnover rates

- improved health and well-being

- higher performance

- a greater display of personal initiative and proactive behaviour (Bakker \& Demerouti, 2008; Schaufeli \& Salanova, 2007).

Thus, investing in conditions which foster work engagement amongst employees is vital for the growth and prosperity of organisations. We can therefore conclude that research supports the link between work engagement and performance, and that work engagement can make a true difference for employees, and may offer organisations a competitive advantage.

Furthermore, the Corporate Leadership Council (2004) has completed a global study of the work engagement level of 50000 employees around the world (27 countries), and its direct impact on both employee performance and retention. This survey clearly indicated that the cost of disengaged employees is too high for any organisation to ignore. The Corporate Leadership Council (CLC) found that those employees who are most committed perform $20 \%$ better and are $87 \%$ less likely to leave the organisation - demonstrating the significance of work engagement to organisational performance. An investigation into both rational and emotional forms of work engagement reveals that emotional engagement is four times more important than rational engagement in driving employee effort.

Hakanen et al. (2008) reported that the dimensions of work engagement and depression correlated negatively, whilst Schaufeli et al. (2008) confirmed that vigour and dedication were negatively related to depression. The causal effect between engagement and depression, however, has not been established in the literature. It is not the intention of this article to explore causal effects between engagement and depression. However, the negative correlations found between engagement and depression, as discussed above, might suggest that an increase in depression could be associated with a decrease in work engagement. Such a link will be very meaningful, because both constructs play an important role in the workplace.

- Hypothesis 2: The work engagement levels of individuals who are unsure whether or not they suffer from depression will be higher than that of individuals who suffer from depression (and receive treatment) and lower than that of individuals who do not suffer from depression.

\section{Burnout and depression}

Burnout can be described as a type of extended response to chronic emotional and interpersonal stressors on the job (Maslach \& Jackson, 1981). It is an individual stress experience embedded in a framework of complex social relationships. More particularly, burnout is defined as follows:

- an overwhelming exhaustion

- feelings of cynicism and detachment from the job

- a sense of ineffectiveness and lack of accomplishment (Maslach, 1993).

Exhaustion involves cognitive and emotional exhaustion. Cognitive exhaustion includes difficulty in making decisions and concentrating, whilst emotional exhaustion entails feeling depleted of one's emotional resource. Cynicism can be seen as a negative or detached response to various aspects of one's work (Maslach \& Jackson, 1981).

Burnout has extensive effects on both the employee and the organisation. It is related to different forms of job withdrawal, including absenteeism, intention to leave the job, and actual turnover; and it also has the potential to influence an employee's health (Maslach et al., 2001). Various studies found that burnout is positively associated with absenteeism as a result of illness (Bakker, Demerouti, De Boer \& Schaufeli, 2003; Lawson \& O'Brien, 1994; Price \& Spence, 1994). Recently, a study using a large representative Finnish sample found that employees with high burnout scores had 52 more absent sick days during the 2 year study period than employees with low burnout scores (Ahola et al., 2008).

Employees who suffer from burnout whilst attempting to continue with their work are considered to experience lower productivity and affectivity at work. This results in decreased job satisfaction and lower levels of dedication and loyalty towards their jobs or organisation (Maslach et al., 2001). 
Burnt out employees show a lack of commitment and are less capable of providing sufficient services, mainly when it comes to aspects such as decision-making, thinking creatively and dealing with clients (Levert, Lucas \& Ortlepp, 2000; Sammut, 1997; Fryer, Poland, Bross \& Krugman, 1988). Employees suffering from high levels of burnout are characterised by cognitive impairment and report symptoms such as an inability to concentrate, forgetfulness, and difficulty with solving complex tasks (Hoogduin, Schaap, Methorst, Peters van Neyenhof \& Van de Griendt, 2001). Burnout directly affects employees in these ways and it also has an indirect effect on the organisation.

Lindblom, Linton, Fedeli and Bryngelsson (2006) suggest that burnout manifests through exhaustion, cynicism and reduced professional efficacy, and is associated with other kinds of psychological distress, such as depression, anxiety, and insomnia. These authors found a significant relation between psychological distress (depression) and burnout. Hakanen et al. (2008) found that burnout predicts future depression, whilst Bakker et al. (2000) indicate that burnout and depression are definitely related as emotional exhaustion and depression share a variance of approximately 20\% (Glass, McKnight \& Valdimarsdottir, 1993; Iacovides, Fountoulakis, Kaprinis \& Kaprinis, 2003) although these are each distinct concepts. This is supported by research confirming the discriminant validity between burnout and depression (Bakker et al., 2000; Brenninkmeyer, Van Yperen \& Buunk, 2001; Glass et al., 1993). Burnout is a work-related phenomenon, whereas depression is more pervasive and context free in nature. Schaufeli et al. (2008) also confirm the relation between burnout and depression. In a study conducted by Nyklíček and Pop (2005), it was apparent that after research controlling for background variables, the strongest predictor of burnout was current depressive symptomatology. In addition to this, persons who currently have depression or who had depression at any time in their lives, and individuals with a family history of depression showed considerably higher burnout levels than individuals who did not have these characteristics (Nyklíček \& Pop, 2005).

- Hypothesis 3: The burnout levels of individuals who are unsure whether they suffer from depression will be lower than those of individuals who suffer from depression (and receive treatment) and higher than those of individuals who do not suffer from depression.

\section{Stress-related ill health and depression}

Health can be defined as 'a state of complete physical, mental, and social well-being and not merely the absence of disease, or infirmity' (World Health Organisation, 2001). A distinction can be made between two types of stressrelated ill health, namely stress-related physical ill health and stress-related psychological ill health. Stress-related ill health involves stress-related ill health symptoms that are caused by or associated with stress. Stress-related physical ill health refers to physical symptoms of stress, including sleeping disorders, changes in appetite, muscle tenderness, headaches, gastrointestinal problems and palpitations. Stress-related psychological ill health refers to psychological symptoms of stress, including:

- irritability

- low energy levels

- difficulty to concentrate

- loss of sense of humour

- apprehensiveness

- avoiding contact with people

- panic or anxiety attacks

- mood swings

- prolonged feelings of sadness or worthlessness (Rothmann \& Rothmann, 2006).

Stress-related ill health is related to a multitude of negative outcomes for organisations, such as increased health care costs, substance abuse, reduced productivity, turnover and legal problems, as well as violence and increased absenteeism (Geurts \& Demerouti, 2003; Reid, 2009). Stress-related ill health is one of the greatest contributors to absenteeism, and statistics show that healthy employees take up to nine times fewer sick days than their unhealthy colleagues. They also make up to $60 \%$ fewer errors. In essence, it is more costeffective in the long term for organisations to take care of their employees' mental and physical health than to make alternative arrangements for low productivity levels and excessive sick leave (Reid, 2009).

Depression is an illness that is considered by some to have a more vital impact on work performance than that of chronic forms of illness like arthritis, hypertension, back problems and diabetes (Wells et al., 1989; Kessler \& Greenberg, 2001). It is a destructive and disabling disease that affects many aspects of an individual's life, including the work domain. Depression can also bring about problems such as absenteeism, job turnover, difficulty making decisions, a decline in productivity and an increase in alcohol consumption (Johnson \& Indvik, 1997).

According to Pinto (2005), depression is frequently seen in association with chronic medical illness and leads to increased morbidity, mortality and healthcare costs. Depression usually worsens an individual's physical ill health more indirectly by interfering with their willingness to partake in rehabilitation and by associated poor diet, lack of exercise and overall poorer self-care, (Smyth, 2009). Evidence from a study conducted by Keenan-Miller, Hammen and Brennan (2007) suggests that depression is associated with poor health outcomes. In addition, individuals who suffer from depression, seem to be more likely to feel that they are susceptible to physical illness (Levinson \& Druss, 2005). Lastly, a study by Sharpley, Bitsika and Efremidis (1997) suggested that stress-related ill health contributes to an individual's depressive symptoms.

- Hypothesis 4: The stress-related ill health symptoms of individuals who are unsure whether or not they suffer from depression will be more than that of individuals who suffer from depression (and receive treatment) and less than that of individuals who do not suffer from depression. 
Concerning the relationships between depression and work engagement, burnout and stress-related ill health, it can thus be concluded that people who suffer from depression will experience low work engagement levels, high burnout levels and more stress-related ill health symptoms than people who do not suffer from depression. Although these relationships have been established between depression and the three wellbeing constructs, it remains unclear how these relationships will differ for the three different groups included in this study. Furthermore, it can be concluded that although depression is prevalent in almost all populations, it is unclear what the exact prevalence of self-reported depression is in a large population group within South Africa.

The general aim of this study is therefore to determine the prevalence of depression in a large working population in South Africa and to determine whether or not work engagement, burnout and stress-related ill health levels differ amongst individuals across different sectors in South Africa in the three groups of participants.

\section{Research design \\ Research approach}

This study is quantitative in nature. Quantitative research is a form of conclusive research involving large representative samples and moderately structured data collection procedures (Struwig \& Stead, 2001). A cross-sectional research design was also followed for the purposes of this study, suggesting that the data were collected at a single point in time (Trochim \& Donnelly, 2007). Primary data were used and a correlational approach was followed to analyse the data.

\section{Research method Research participants}

The study population consisted of 15664 participants from several sectors in South Africa, including academic institutions, call centres, financial institutions, government departments, manufacturing industries and mining houses. An availability sample strategy was followed and the study population included both genders and individuals with various marital statuses (single, engaged, married, divorced or widowed), between the ages of 20 and 60. Participants were from all South African demographic groups and had different levels of education, varying from primary to tertiary education. Lastly, the study population represented all nine provinces in South Africa and participants from all eleven official languages. The study population was thus representative of the diverse nature of South Africa. Table 1 shows the characteristics of the participants.

The study population consisted mainly of participants working in the financial sector $(40.7 \%)$. Furthermore, the population mainly consisted of males $(61.9 \%)$, of whom $62.3 \%$ were married and $28.2 \%$ of whom were between the ages of 30 and 39 years. The Black racial group $(29.8 \%)$, Coloured racial group (3.9\%), Indian racial group (2.5\%) and White racial group (36\%) were represented, of whom 50.5\% completed grade 12 . Of the participants, $47.2 \%$ resided in Gauteng, $38.2 \%$ of the participants were Afrikaans-speaking and $29.7 \%$ were English-speaking.

TABLE 1: Characteristics of the participants ( $n=15664)$.

\begin{tabular}{|c|c|c|c|}
\hline Item & Category & Frequency & $\%$ \\
\hline \multirow[t]{2}{*}{ Gender } & Male & 9697 & 61.90 \\
\hline & Female & 5966 & 38.10 \\
\hline \multirow[t]{5}{*}{ Race } & Black & 4675 & 29.80 \\
\hline & Coloured & 609 & 3.90 \\
\hline & Indian & 395 & 2.50 \\
\hline & White & 5638 & 36.00 \\
\hline & Not Indicated & 4675 & 29.80 \\
\hline \multirow[t]{12}{*}{ Language } & Afrikaans & 5982 & 38.20 \\
\hline & English & 4652 & 29.70 \\
\hline & Sesotho & 1200 & 7.70 \\
\hline & isizulu & 1018 & 6.50 \\
\hline & Setswana & 849 & 5.40 \\
\hline & isiXhosa & 741 & 4.70 \\
\hline & Sepedi & 504 & 3.20 \\
\hline & Xitsonga & 202 & 1.30 \\
\hline & Siswati & 181 & 1.20 \\
\hline & Tshivenda & 112 & 0.70 \\
\hline & isiNdebele & 100 & 0.60 \\
\hline & Other & 121 & 0.80 \\
\hline \multirow[t]{6}{*}{ Marital status } & Married & 9761 & 62.30 \\
\hline & Single & 4497 & 28.70 \\
\hline & Divorced & 955 & 6.10 \\
\hline & Engaged & 289 & 1.80 \\
\hline & Widow & 111 & 0.70 \\
\hline & Widower & 50 & 0.30 \\
\hline \multirow[t]{9}{*}{ Education level } & Grade 8 & 2003 & 12.80 \\
\hline & Grade 9 & 119 & 0.80 \\
\hline & Grade 10 & 679 & 4.30 \\
\hline & Grade 11 & 299 & 1.90 \\
\hline & Grade 12 & 7914 & 50.50 \\
\hline & 4 Year Degree/Diploma & 1075 & 6.90 \\
\hline & 5-7 Year Degree & 213 & 1.40 \\
\hline & Master`s Degree & 446 & 2.80 \\
\hline & Doctoral Degree & 70 & 0.40 \\
\hline \multirow[t]{9}{*}{ Province } & Gauteng & 7390 & 47.20 \\
\hline & North West Province & 3171 & 20.20 \\
\hline & Mpumalanga & 2293 & 14.60 \\
\hline & Free State & 887 & 5.70 \\
\hline & Western Cape & 691 & 4.40 \\
\hline & Kwa-Zulu Natal & 630 & 4.00 \\
\hline & Eastern Cape & 343 & 2.20 \\
\hline & Limpopo & 143 & 0.90 \\
\hline & Northern Cape & 74 & 0.50 \\
\hline \multirow[t]{7}{*}{ Sector } & Financial & 6370 & 40.70 \\
\hline & Mining & 5197 & 33.20 \\
\hline & Manufacturing & 3467 & 22.10 \\
\hline & Government & 263 & 1.70 \\
\hline & Call centres & 150 & 1.00 \\
\hline & Academic & 94 & 0.60 \\
\hline & Other & 122 & 0.80 \\
\hline \multirow[t]{7}{*}{ Age } & Younger than 20 & 82 & 0.50 \\
\hline & $20-29$ & 4064 & 25.90 \\
\hline & $30-39$ & 4414 & 28.20 \\
\hline & $40-49$ & 4341 & 27.70 \\
\hline & $50-59$ & 2324 & 14.80 \\
\hline & Older than 60 & 200 & 1.30 \\
\hline & Missing values & 238 & 1.50 \\
\hline
\end{tabular}




\section{Measuring instruments}

The following questionnaires were used in the empirical study.

A biographical questionnaire was administered in order to record the socio-demographic and biographical data of the participants, including age, gender, race, language, marital status and their level of education. The geographic location and sector of work were also determined.

The South African Employee Health and Wellness Survey (SAEHWS) was followed to measure all four constructs, namely, (1) depression, (2) work engagement, (3) burnout and (4) stress-related ill health (Rothmann \& Rothmann, 2006). The SAEHWS is a self-report instrument based on the dualprocess model of work-related well-being. The SAEHWS assumes that the perceptions and experiences of employees can represent important information regarding the wellness climate in the organisation. An employee's health and wellness status is measured by the SAEHWS. The SAEHWS then relates the measured data to the organisational climate and also compares the results to the South African norm (Rothmann \& Rothmann, 2006). Rothmann and Rothmann (2006) reported that the internal consistency of the SAEHWS is acceptable, with a Cronbach alpha coefficient above 0.70 .

The sections of the SAEHWS measuring depression, work engagement, burnout and stress-related ill health were used for the purposes of this study.

To determine whether or not an individual suffers from depression, the following scale was used:

- 'yes' (currently being medically treated for depression)

- 'unsure whether suffering from depression'

- 'not suffering from depression'.

Burnout was measured using a 7-point Likert-type rating scale, ranging from 0 ('never') to 6 ('always'). The measure of the exhaustion dimension $(\alpha=0.84)$ consisted of five items (e.g. 'I feel tired before I arrive at work'), and five items were also used to measure cynicism ( $\alpha=0.81$ ) (e.g. 'I have become less enthusiastic about my work'). Work engagement consists of two dimensions, namely vigour and dedication. Five items were used to measure vigour ( $\alpha=0.84$ ) (e.g. 'I am full of energy in my work'), whilst another five items measured dedication $(\alpha=0.83)$ (e.g. 'I am passionate about my job'). The measure of stress-related ill health utilises a 4-point Likerttype rating scale, ranging from 1 ('never') to 4 ('always') and includes the subscales stress-related psychological ill health $(\alpha=0.78)$, which includes several symptoms, like 'mood swings', and stress-related physical ill health $(\alpha=0.77)$, which includes several symptoms, like 'headaches'.

\section{Research procedure}

This project was undertaken in collaboration with Afriforte (Pty) Limited. Data collected between 2007 and 2010 was used for this study. Informed consent was obtained from all the participants and all the participants received a link to the internet-based survey via e-mail.

\section{Statistical analysis}

The statistical analysis was carried out by means of the SPSS programme (SPSS, 2008). To analyse the data, descriptive statistics (e.g. means, standard deviations) were used. Pearson product-moment correlation coefficients were used to specify the relationship between the variables. In terms of statistical significance, the value was set at a $95 \%$ confidence interval level $(p<0.05)$. Effect sizes (Steyn, 2000) were used to determine the practical significance of the findings. A cutoff point of 0.30 (medium effect, Cohen, 1988) was set for the practical significance of correlation coefficients.

Frequencies were used to determine the prevalence of depression in the three different groups.

Multivariate analysis of variance (MANOVA) was used to determine the significance of differences between the levels of work engagement, burnout and ill-health symptoms of individuals in the three groups of participants.

MANOVA tests whether or not mean differences, amongst groups on a combination of dependent variables, are likely to have occurred by chance (Tabachnick \& Fidell, 2001). In MANOVA, a new dependent variable that maximises group differences is created from the set of dependent variables. Wilk's Lambda was used to test the likelihood of the data under the assumption of equal population mean vectors for all groups, against the likelihood under the assumption that the population mean vectors are identical to those of the sample mean vectors for the different groups. When an effect is significant in MANOVA, one-way analysis of variance (ANOVA) was used to determine which dependent variables were affected. Because multiple ANOVAs were used, a Bonferroni-type adjustment was made for an inflated Type 1 error. The Games-Howell procedure was used to determine whether or not statistical differences exist between the groups.

\section{Results}

Acceptable Cronbach alpha coefficients were obtained for all the scales. All the alpha coefficients were higher than the guideline of $\alpha>0.70$ (Nunnally \& Bernstein, 1994).

TABLE 2: Descriptive statistics and Cronbach alpha coefficients of the measuring instruments $(n=15664)$.

\begin{tabular}{llll}
\hline Item & Mean & SD & $\boldsymbol{\alpha}$ \\
\hline Depression & 2.47 & 0.78 & n/a† \\
Vigour & 22.30 & 5.45 & 0.84 \\
Dedication & 23.28 & 6.04 & 0.83 \\
Exhaustion & 13.16 & 6.38 & 0.84 \\
Cynicism & 7.18 & 5.52 & 0.81 \\
Stress-related psychological ill health & 17.76 & 6.39 & 0.78 \\
Stress-related physical ill health & 12.82 & 4.45 & 0.77 \\
\hline
\end{tabular}

SD, standard deviation; $\alpha$, Cronbach alpha.

$\dagger$, In the SAEWHS depression is measured by using only one self-report item, therefore no alpha is available. 
TABLE 3: Correlation coefficients between depression, work engagement, burnout and stress-related ill health $(n=15664)$.

\begin{tabular}{|c|c|c|c|c|c|c|c|}
\hline Coefficients & 1 & 2 & 3 & 4 & 5 & 6 & 7 \\
\hline 1. Depression & 1.00 & - & - & - & - & - & - \\
\hline 2. Vigour & $-0.34 \dagger \dagger$ & 1.00 & - & - & - & - & - \\
\hline 3. Dedication & $-0.26 \dagger$ & $0.76+t$ & 1.00 & - & - & - & - \\
\hline 4. Exhaustion & $0.35 \dagger t$ & $-0.53 \dagger \S$ & $-0.38 \dagger+$ & 1.00 & - & - & - \\
\hline 5. Cynicism & $0.30 \dagger$ & $-0.58+\S$ & $-0.61 \dagger \S$ & $0.51 \uparrow \S$ & 1.00 & - & - \\
\hline 6. Stress-related physical ill health & $0.45 \dagger t$ & $-0.41 \dagger \dagger$ & $-0.28 \dagger$ & $0.54 \uparrow \S$ & $0.36+t$ & 1.00 & - \\
\hline 7. Stress-related psychological ill health & $0.51 \dagger \dagger$ & $-0.54 \uparrow \S$ & $-0.41 \dagger \dagger$ & $0.61 \dagger \S$ & $0.50 \dagger \dagger$ & $0.73 \uparrow \S$ & 1.00 \\
\hline
\end{tabular}

$\dagger$, Correlation is significant at the 0.01 level.

$\star$. Correlation is practically significant $r>0.30$ (medium effect).

$\$$, Correlation is practically significant $r>0.50$ (large effect).

Table 3 indicates that stress-related psychological ill health is statistically and practically significantly related (with a large effect) to depression (positive relationship), vigour (negative relationship) and exhaustion (positive relationship). It is statistically and practically significantly related with a medium effect to dedication (negative relationship) and cynicism (positive relationship). A statistical and practical significance with a large effect has been established between physical stress-related ill health and exhaustion (positive relationship); and a practical significance, with a medium effect, has been established between physical stress-related ill health and depression (positive relationship), vigour (negative relationship) and cynicism (positive relationship). Cynicism is statistically and practically significantly related (with a large effect) to vigour (negative relationship), dedication (negative relationship) and exhaustion (positive relationship). Exhaustion is statistically and practically significantly related, with a large effect, to vigour (negative relationship); and practically significantly related with a medium effect to depression (positive relationship) and dedication (negative relationship). A statistical and practical significance with a large effect has been established between dedication and vigour (positive relationship). Lastly, Table 3 shows that vigour is statistically and practically significantly related with a medium effect to depression (negative relationship).

To calculate the prevalence of depression in the three different groups, as illustrated in Table 4, frequencies were used.

Table 4 illustrates that approximately one-fifth of the population suffered from depression and were receiving treatment for it, a little less than one-fifth of the population were unsure whether or not they suffered from depression, and the remainder of the population did not suffer from depression.

Next, MANOVA was used to determine differences in work engagement, burnout and stress-related ill health levels amongst the three different depression groups (suffering from depression; unsure; and not suffering from depression). Results were first analysed for statistical significance, using Wilk's Lambda statistics. ANOVA was used to determine specific differences if a statistical difference was found. The results of the MANOVA analyses are given below in Table 5 .
In an analysis of Wilk's Lambda values, a statistically significant difference $(p \leq 0.05)$ regarding work engagement, burnout and stress-related ill health levels was found amongst the different depression groups and was further analysed using ANOVA. Owing to differences in sample sizes, the Games-Howell procedure was used to determine whether or not there were any statistical differences amongst the groups.

The results of the three ANOVAs follow in Table 6, Table 7 and Table 8 .

Table 6 shows statistically significant differences between levels of vigour and dedication for each of the three groups. Not depressed participants experience higher levels of vigour than unsure participants and depressed participants. Not depressed participants also experience higher levels of dedication than unsure participants and depressed participants.

Table 7 shows statistically significant differences between levels of exhaustion and cynicism for participants in the three categories according to their depression state, that is depressed, unsure about depression and not depressed. Depressed participants and unsure participants experience higher levels of cynicism than participants who do not suffer from depression.

TABLE 4: Frequencies illustrating the prevalence of depression in the three depression groups.

\begin{tabular}{llll}
\hline Item & Category & Frequency & $\%$ \\
\hline Depression & $\begin{array}{l}\text { Group 1: Suffering from depression } \\
\text { Group 2: Unsure whether or not } \\
\text { suffering from depression }\end{array}$ & 2865 & 18.3 \\
& $\begin{array}{l}\text { Group 3: Not suffering from } \\
\text { depression }\end{array}$ & 10186 & 16.7 \\
\hline
\end{tabular}

TABLE 5: MANOVA - Differences in work engagement, burnout and stressrelated ill health levels of depression groups.

\begin{tabular}{llllll}
\hline Variable & Value & $\boldsymbol{F}$ & $\boldsymbol{d f}$ & $\boldsymbol{p}$ & $\begin{array}{l}\text { Partial eta } \\
\text { squared }\end{array}$ \\
\hline Depression & 0.70 & 515.11 & 12 & $0.00^{*}$ & 0.17 \\
\hline
\end{tabular}

$F$, frequency; $d f$, degree of freedom; $p$, probability value.

$*, p \leq 0.05=$ statistically significant.

TABLE 6: ANOVA - Differences in work engagement levels based on depression group.

\begin{tabular}{llllll}
\hline Item & Yes & Unsure & No & $\boldsymbol{P}$ & $\begin{array}{l}\text { Partial eta } \\
\text { squared }\end{array}$ \\
\hline Vigour & 19.26 & 20.33 & 23.67 & $0.00^{*}$ & 0.12 \\
Dedication & 20.79 & 21.38 & 24.46 & $0.00^{*}$ & 0.07 \\
\hline
\end{tabular}

$P$, probability value.

$*, p \leq 0.05$ = statistically significant. 
TABLE 7: ANOVA - Differences in burnout levels based on depression group

\begin{tabular}{llllll}
\hline Item & Yes & Unsure & No & $\boldsymbol{P}$ & $\begin{array}{l}\text { Partial eta } \\
\text { squared }\end{array}$ \\
\hline Exhaustion & 16.94 & 15.46 & 11.50 & $0.00^{*}$ & 0.13 \\
Cynicism & 9.81 & 9.03 & 5.97 & $0.00^{*}$ & 0.09 \\
\hline
\end{tabular}

$P$, probability value.

$*, p \leq 0.05$ = statistically significant.

TABLE 8: ANOVA - Differences in stress-related ill health levels based on depression group.

\begin{tabular}{lccccl}
\hline Item & Yes & Unsure & No & $\boldsymbol{P}$ & $\begin{array}{l}\text { Partial eta } \\
\text { squared }\end{array}$ \\
\hline $\begin{array}{l}\text { Stress-related psychological } \\
\text { ill health }\end{array}$ & 23.47 & 21.07 & 15.31 & $0.00 *$ & 0.29 \\
$\begin{array}{l}\text { Stress-related physical ill } \\
\text { health }\end{array}$ & 16.22 & 14.84 & 11.34 & $0.00 *$ & 0.21 \\
\hline
\end{tabular}

$P$, probability value.

$*, p \leq 0.05=$ statistically significant.

Table 8 shows statistically significant differences between levels of stress-related psychological ill health and stressrelated physical ill health. Depressed participants and unsure participants experience higher levels of stress-related psychological ill health than not depressed participants. Also, depressed participants and unsure participants experience higher levels of stress-related physical ill health than not depressed participants.

\section{Discussion}

The general aim of this study was to determine the prevalence of depression in the study population and to establish whether or not work engagement, burnout and stress-related ill health levels differ amongst individuals across different sectors in South Africa in the three groups of participants, namely the (depressed group), the (unsure group) and the (not depressed group).

Cronbach alpha coefficients varying from 0.77 to 0.84 were obtained for the different constructs. All the alpha coefficients were higher than the guideline of $\alpha>0.70$ (Nunnally \& Bernstein, 1994). Most of the constructs, except depression and dedication, had normal distributions, with acceptable levels of skewness and kurtosis.

Pearson product-moment correlations were conducted to determine the relationship between the variables. The results obtained indicated a negative correlation between depression and vigour and dedication, meaning that an individual who suffers from depression is expected to experience low vigour and dedication levels. Several previous studies have found similar results (Hakanen et al., 2008; Schaufeli et al., 2008). Depression furthermore, correlated positively with exhaustion, cynicism, stress-related psychological ill health and stress-related physical ill health, indicating that an individual who suffers from depression could be expected to have high levels of exhaustion and cynicism, and exhibit increased stress-related symptoms of psychological and physical ill health. This corresponds with the results of previous studies (Levinson \& Druss, 2005; Nyklíček \& Pop, 2005; Sharpley et al., 1997).

\section{The prevalence of depression in South African organisations}

The prevalence of depression amongst the three groups with different depression statuses, in South Africa, were found to be $18.3 \%$ for the depressed group (receiving medical treatment), $16.7 \%$ for the unsure group, and $65 \%$ for the not depressed group. Hypothesis 1 can therefore be confirmed. The prevalence of depression found in this study is higher than the prevalence of depression reported in other countries (Kessler et al., 2003). For example, the World Health Organisation (2001) has found the prevalence of depression to be $7 \%$ in Brazil, almost $10 \%$ in Germany and $4.2 \%$ in Turkey. This serves as proof of the extent of the problem.

Next, MANOVA and ANOVA were used to determine significant differences in work engagement, burnout and stress-related ill health levels of the three different depression groups (suffering from depression, unsure, and not suffering from depression).

\section{Depression and work engagement}

Statistically significant differences between levels of vigour and dedication were found for the three different groups. Hypothesis 2 can also be confirmed, as not depressed participants experienced higher levels of vigour and dedication than unsure participants and depressed participants. This indicates that depressed individuals and unsure individuals experience significantly lower work engagement levels than individuals who do not suffer from depression. This was also found in a recent study by Schaufeli et al. (2008). One possible explanation for this finding is rooted in the literature on affect. The negative affect generally associated with depression may be the cause for a decline in work engagement levels of individuals suffering from depression (Bosman, Rothmann \& Buitendach, 2005). Also, the fact that individuals suffering from depression tend to experience lower levels of energy (associated with vigour), an inability to derive pleasure from things (associated with dedication) and an inability to concentrate (associated with absorption), may explain the lower levels of work engagement.

\section{Depression and burnout}

Statistically significant differences were also found with regard to exhaustion and cynicism. The burnout levels of unsure individuals are lower than that of depressed individuals and higher than not depressed individuals. Thus, hypothesis 3 can be confirmed. It can be concluded that depressed individuals and unsure individuals experience significantly higher levels of burnout than not depressed individuals. A possible explanation for the higher burnout levels amongst depressed individuals and unsure individuals might be that 'good mental health, including absence of (a vulnerability to) depression, protects them against work stress, attenuating the risk to get involved in the burnout process' (Nyklíček \& Pop, 2005, p. 67). 


\section{Depression and ill health symptoms}

Statistically significant differences were also found between levels of stress-related psychological ill health and stressrelated physical ill health. Depressed participants and unsure participants experience higher levels of both stress-related psychological ill health and stress-related physical ill health than not depressed participants, confirming hypothesis 4. This means that depressed individuals and unsure individuals experience significantly more stress-related ill health symptoms than individuals who do not suffer from depression. These findings correspond with those of various researchers such as Werngren-Elgström, Dehlin and Iwarsson (2003) who reported that individuals suffering from depression tend to report lower levels of subjective physical, mental and social well-being and similarly, Little et al. (2001) reported that depression is related to perceived health, somatic symptoms, health and anxiety.

\section{Conclusion}

It was found that both groups, individuals who reported that they suffer from depression and individuals who reported that they are unsure whether or not they suffer from depression, may tend to experience lower work engagement levels, higher burnout levels and more symptoms of stress-related ill health, than individuals who reported that they do not suffer from depression. This finding could have a significant bearing in the workplace. Even more concerning are the small differences in the scores of work engagement, burnout and stress-related ill health symptoms, when comparing the group of individuals who suffer from depression and the group of individuals who are unsure whether or not they suffer from depression. Thus, individuals who are unsure whether or not they suffer from depression might be at a great risk. A possible reason why individuals are unsure if they suffer from depression may be that they already experience some symptoms associated with depression, although they have not been diagnosed with depression yet. This may be because they also experience lower levels of work engagement, higher levels of burnout and more stress-related ill health symptoms. This could increase the prevalence of depression in the study populations from $18.3 \%$ to $35 \%$, implying that more than one third of this large population suffers from some form of depression to some extent.

The question then arises: why do individuals who suffer from depression and receive medical treatment for their condition still seem to suffer from lower work engagement levels, higher burnout levels and more stress-related ill health symptoms? According to Kline and Sussman (2000), managerial responses to employee depression too often reflect a poor understanding of successful treatment and unreasonable expectations concerning the time required for successful treatment. Kline and Sussman (2000) also indicate that although antidepressants typically produce a faster treatment response than therapy alone, the response time remains much longer than that for an antibiotic, for example. Antidepressants produce molecular changes in the brain which occur only after several weeks of treatment. Some patients also do not respond to the initial treatment with medication. In such instances, the psychiatrist (who subscribes the medicine) will probably increase the dose, change medication, or add an augmenting agent, each requiring several weeks to evaluate its therapeutic effect (Goldman, McCulloch \& Sturm, 1998).

\section{Limitations and recommendations}

Although the research shows promising results, it was not without its limitations. The first limitation of this study was the cross-sectional research design used in this study. This meant that no causal inferences could be made. Therefore, in future studies, a longitudinal design should be used. A further limitation is that the results were obtained solely by self-report measures. This may lead to a problem known as 'method variance' or 'nuisance'. However, several authors argue that this phenomenon is not a major threat if interactions are found (Spector, 1992; Semmer, Zapf \& Greif, 1996; Dollard \& Winefield, 1998). The fact that depression was measured by means of only one item in the SAEHWS can also be viewed as a limitation. A more extensive way of measuring depression is suggested for future researchers. A further limitation may be the way in which depression was defined in this study. For the purposes of this study, an individual who is receiving medical treatment for depression was defined as an individual who suffers from depression. However, there are various types of depression, for instance major depressive disorder, bipolar disorder and dysthymia, to name but a few of them. Because the work engagement levels, burnout levels and the occurrence of stress-related ill health symptoms may vary for individuals suffering from different types of depression, it is suggested that future studies differentiate amongst the different types of depression when exploring the relationship of depression with work engagement, burnout and stress-related ill health.

Despite these limitations, the findings of this study may have important implications for future research and more specific practices in the workplace. To become aware of the problems of depression, it is advised that organisations investigate and undertake an extensive analysis of what the actual prevalence of depression is in their own organisation, and also how it will affect their specific sector. Organisations could invest in longterm programmes to educate management and employees about the existence and consequences of depression, and how to manage it in the workplace. Employees should be encouraged to seek treatment. By making treatment easily obtainable and by providing the correct support, employers will benefit in the long run. The drafting of an extensive policy will provide clear guidelines for both management and employees, concerning treatment. A multidisciplinary approach is strongly advised, with the collaboration of the organisation's industrial psychologist or human resource practitioner as co-ordinator. 


\section{Acknowledgements Competing interests}

The authors declare that they have no financial or personal relationship(s) which may have inappropriately influenced them in writing this paper.

\section{Authors' contributions}

C.W. (North-West University) completed this evaluation as a requirement for her Master's degree. C.E. (North-West University) supervised the evaluation.

\section{References}

Ahola, K., \& Hakanen, J. (2007). Job strain, burnout, and depressive symptoms: A prospective study among dentists. Journal of Affective Disorders, 104, 103-110. http://dx.doi.org/10.1016/j.jad.2007.03.004, PMid:17448543

Ahola, K., Honkonen, T., Isometsä, E., Kalimo, R., Nykyri, E., Aromaa, A. et al. (2005). The relationship between job-related burnout and depressive disorders: Results from the Finnish Health 2000 Study. Journal of Affective Disorders, 88, 55-62. http://dx.doi.org/10.1016/j.jad.2005.06.004, PMid:16038984

Ahola, K., Kivimäki, M., Honkonen, T., Virtanen, M., Koskinen, S., Vahtera, J. et al. (2008). Occupational burnout and medically certified sickness absence: A population-based study of Finnish employees. Journal of Psychosomatic Research, 64, 185-193. http://dx.doi.org/10.1016/j.jpsychores.2007.06.022, PMid:18222132

American Psychiatric Association. (1994). Diagnostic and statistical manual of mental disorders (DSM-IV). (4th edn.). Washington, DC: APA

Bakker, A.B. (2009). Building engagement in the workplace. In C. Cooper \& R. Burke (Eds.), The peak performing organization, (pp. 50-72). London: Routledge. http:// (Eds.), The peak performing organization,
dx.doi.org/10.4324/9780203971611.ch3

Bakker, A.B., \& Demerouti, E. (2008). Towards a model of work engagement. Career Development International, 13(3), 209-223. http://dx.doi. org/10.1108/13620430810870476

Bakker, A.B., Demerouti, E., De Boer, E., \& Schaufeli, W.B. (2003). Job demands and job resources as predictors of absence duration and frequency. Journal of Vocational Behavior, 62, 341-356. http://dx.doi.org/10.1016/S0001-8791(02)00030-1

Bakker, A.B., Schaufeli, W.B., Demerouti, E., Janssen, P.P.M., Van der Hulst, R., \& Brouwer, J. (2000). Using Equity Theory to Examine the Difference Between Burnout and Depression. Anxiety, Stress \& Coping: An International Journal, 13(3), 247-268.

Barkhuizen, N., \& Rothmann, S. (2006). Work engagement of academic staff in South African higher education institutions. Management Dynamics, 15(1), 38-48.

Bosman, J., Rothmann, S., \& Buitendach, J.H. (2005). Job insecurity, burnout and work engagement: The impact of positive and negative affectivity. South African Journal engagement: The impact of positive and
of Industrial Psychology, 31(4), 48-56.

Brenninkmeyer, V., Van Yperen, N.W., \& Buunk, B.P. (2001). Burnout and depression are not identical twins: is decline of superiority a distinguishing feature? Personality and Individual Differences, 30(5), 873-880. http://dx.doi.org/10.1016/S0191 8869(00)00079-9

Coetzer, C.F., \& Rothmann, S. (2007). Job demands, job resources and work engagement of employees in a manufacturing organisation. Southern African Business Review, 11(3), 17-32.

Cohen, J. (1988). Statistical power analysis for the behavioural sciences. (2nd edn.) Orlando, CA: Academic Press.

Corporate Leadership Council. (2004). Driving performance and retention through employee engagement. Washington, DC: Corporate Executive Board.

Demerouti, E., Bakker, A.B., Janssen, P.P.M., \& Schaufeli, W.B. (2001). Burnout and engagement at work as a function of demands and control. Scandinavian Journal of Work, Environment \& Health, 27, 279-286. http://dx.doi.org/10.5271/ sjweh.615

Dollard, M.F., \& Winefield, A.H. (1998). A test of the demand-control/support model of work stress in correctional officers. Journal of Occupational Health Psychology, 3, 1-23. http://dx.doi.org/10.1037/1076-8998.3.3.243, PMid:9684215

Druss, B.G., Rosenheck, R.A., \& Sledge, W.H. (2000). Health and disability costs of depressive illness in a major U.S. corporation. American Journal of Psychiatry, 157(8), 1274-1278. http://dx.doi.org/10.1176/appi.ajp.157.8.1274, PMid:10910790

Freude, G., Seibt, R., Pech, E., \& Ullsperger, P. (2005). Assessment of work ability and vitality: A study of teachers of different age groups. International Congress Series, 1280, 270-274. http://dx.doi.org/10.1016/j.ics.2005.02.099

Fryer, G., Poland, J., Bross, D., \& Krugman, R. (1988). The child protective service worker: A profile of needs, attitudes and utilisation of professional resources. Child Abuse and Neglect, 12, 481-490. http://dx.doi.org/10.1016/0145 2134(88)90065-8

Geurts, S.A.E., \& Demerouti, E. (2003). Work/non-work interface: A review of theories and findings. In M.J. Schabracq, J.A.M. Winnubst \& C.L. Cooper (Eds.), The handbook of work and health psychology, (pp. 279-312). Chichester, UK: Wiley.
Glass, D.C., McKnight, J.D., \& Valdimarsdottir, H. (1993). Depression, burnout, and perceptions of control in hospital nurses. Journal of Consulting and Clinical Psychology, 61(1), 147-155. http://dx.doi.org/10.1037/0022-006X.61.1.147, PMid:8450100

Goldman, W., McCulloch, J., \& Sturm, R. (1998). Costs and use of mental health services before and after managed care. Health Affairs, 17(2), 40-52. http:// dx.doi.org/10.1377/hlthaff.17.2.40, PMid:9558784

González-Romá, V., Schaufeli, W., Bakker, A.B., \& Lloret, S. (2006). Burnout and work engagement: Independent factors or opposite poles? Journal of Vocational Behaviour, 68, 165-174. http://dx.doi.org/10.1016/j.jvb.2005.01.003

Greenberg, P.E., Kessler, R.C., Nells, T.L., Finkelstein, S.N., \& Berndt, E.R. (1996). Depression in the workplace: An economic perspective. In J.P. Feighner, \& W.F. Boyer (Eds.), Selective Serotonin Reuptake Inhibitors: Advances in Basic Research and Clinical Practice, (pp. 327-363). New York: John Wiley \& Sons.

Hakanen, J., Schaufeli, W., \& Ahola, K. (2008). The Job Demands-Resources model: A three-year cross-lagged study of burnout, depression, commitment, and work engagement. Work and Stress, 22(3), 224-241. http://dx.doi. org/10.1080/02678370802379432

Hoogduin, C., Schaap, C., Methorst, G., Peters van Neyenhof, C., \& Van de Griendt J. (2001). Burnout: Klinisch beeld en diagnostiek [Burnout: Clinical description and diagnosis]. In C.A.L. Hoogdduin, W.B. Schaufeli, C.P.D.R. Schaap \& A.B. Bakker (Eds.). Behandelings strategieen bij burnout, (pp. 13-20). Houten: Bohn Stafleu VanLoghum.

lacovides, A., Fountoulakis, K.N., Kaprinis, St., \& Kaprinis, G. (2003). The relationship between job stress, burnout and clinical depression. Journal of Affective Disorders, 75, 209-221. http://dx.doi.org/10.1016/S0165-0327(02)00101-5

Jackson, L.T.B., Rothmann, S., \& Van de Vijver, F.J.R. (2006). A model of work-related well-being for educators in South Africa. Stress and Health, 22, 263-274.

Johnson, P.R., \& Indvik, J. (1997). The boomer blues: Depression in the work-place. Public Personnel Management, 26, 359-369.

Keenan-Miller, D., Hammen, C.L., \& Brennan, P.A. (2007). Health outcomes related to early adolescent depression. Journal of Adolescent Health, 14(3), 256-262.

Kessler, R.C., Berglund, P., Demler, O., Jin, R., Koretz, D., Merikangas, K.R. et al. (2003) The epidemiology of Major Depressive Disorder: Results from the National Comorbidity Survey Replication (NCS-R). The Journal of the American Medical Comorbidity Survey Replication (NCS-R). The Journal of the American Medical Association, 289
PMid:12813115

Kessler, R., \& Greenberg, P. (2001). The effects of chronic medical conditions on work loss and work cutback. Journal of Occupational \& Environmental Medicine, 43(3), loss and work cutback. Journal of Occupational \& Environmental Medicine, 43(3),
218. http://dx.doi.org/10.1097/00043764-200103000-00009, PMid:11285869

Kline, J., \& Sussman, L. (2000). An executive guide to workplace depression. Academy of Management Executive, 14(3), 1-19.

Lawson, D.A., \& O'Brien, R.M. (1994). Behavioral and self-report measures of staff burnout in development disabilities. Journal of Organizational Behavio Management, 14, 37-54. http://dx.doi.org/10.1300/J075v14n02_04

Levert, T., Lucas, M., \& Ortlepp, K. (2000). Burnout in psychiatric nurses: Contributions of the work environment and a Sense of Coherence. South African Journal of Psychology, 30, 36-43.

Levinson, C.M., \& Druss, G. (2005). Health beliefs and depression in a group of elderly high utilizers of medical services. General Hospital Psychiatry, 27(2), 97-99. http://dx.doi.org/10.1016/j.genhosppsych.2004.09.010, PMid:15763120

Lindblom, K.M., Linton, S.J., Fedeli, C., \& Bryngelsson, I. (2006). Burnout in the working population: Relations to psychosocial work factors. International Journal of Behavioral Medicine, 13(1), 51-59. http://dx.doi.org/10.1207/s15327558ijbm1301_7, PMid:16503841

Little, P., Somerville, J., Williamson, I., Warner, G., Moore, M., Wiles, R. et al. (2001). Psychosocial, lifestyle, and health status variables in predicting high attendance among adults. British Journal of General Practice, 51, 977-984. PMid:11766870

Lockwood, N.R. (2007). Leveraging employee engagement for competitive advantage. Society for Human Resource Management Research Quarterly, 1, 1-12.

Macey, W.H., \& Schneider, B. (2008). The meaning of employee engagement. Industrial and Organizational Psychology, 1, 3-30. http://dx.doi.org/10.1111/ Industrial and Organization

Maslach C. (1993). Burnout: A multidimensional perspective. In W.B. Schaufeli, C. Maslach \& T. Marek (Eds.), Professional Burnout: Recent Developments in Theory and Research, (pp. 19-32). Washington, DC: Taylor \& Francis.

Maslach, C., \& Jackson, S.E. (1981). The measurement of experienced burnout. Journa of Occupational Behavior, 2, 99-113. http://dx.doi.org/10.1002/job.4030020205

Maslach, C., Schaufeli, W.B., \& Leiter, M.P. (2001). Job burnout. Annual Review Psychology, 52, 397-422. http://dx.doi.org/10.1146/annurev.psych.52.1.397, PMid:11148311

May, D.R., Gilson, R.L., \& Harter, L.M. (2004). The psychological conditions of meaningfulness, safety and availability and the engagement of the human spirit at work. Journal of Occupational and Organizational Psychology, 77, 11-37. http:// dx.doi.org/10.1348/096317904322915892

McIntyre, R.S., \& O'Donovan, C. (2004). The human cost of not achieving full remission in depression. Canadian Jounal of Psychiatry, 49(1), 10-16.

Montgomery, A.J., Peeters, M.C.W., Schaufeli, W.B., \& Den Ouden, M. (2003). Workhome interference among newspaper managers: Its relationship with burnout and engagement. Anxiety, stress and coping, 16(2), 195-211.

Naudé, J.L.P., \& Rothmann, S. (2004). The validation of the Utrecht work engagement scale for emergency medical technicians in Gauteng. South African Journal of Economic and Managment Sciences, 6(3), 459-468. 
Nevid, J.S., Spencer, A.R., \& Greene, B. (2006). Abnormal psychology in a changing world. (6th edn.). Upper Saddle River, NJ: Pearson.

Nunnally, J.C., \& Bernstein, I.H. (1994). Psychometric theory. (3rd edn.). New York: McGraw-Hill.

Nyklíček, I., \& Pop, V.J. (2005). Past and familial depression predict current symptoms of professional burnout. Journal of Affective Disorders, 88, 63-68. http://dx.doi. org/10.1016/j.jad.2005.06.007, PMid:16054229

Pinto, C. (2005). Depression and medical illness. Medicine Update, 176, 871-873.

Price, L., \& Spence, S.H. (1994). Burnout symptoms amongst drug and alcohol service employees: Gender differences in the interaction between work and home stressors. Anxiety, Stress \& Coping, 7, 67-84. http://dx.doi org/10.1080/10615809408248394

Reid, J. (2009). Healthy employees increase productivity. Retrieved April 10, 2010, from http://securitysa.com/news.aspx?pklNewsld=34180\&pkICategoryID=106

Rothmann, S., \& Jorgensen, L.I. (2007). A model of work-related well-being for police members in the North West province. Acta Criminologica, 20(4), 73-84.

Rothmann, S., \& Pieterse, J. (2007). Predictors of work-related well-being in sector education training authorities. South African Journal of Economic and Managment Science, 10(3), 298-312.

Rothmann, J.C., \& Rothmann, S. (2006). The South African Employee Health and Wellness Survey: User manual. Potchefstroom: Afriforte (Pty) Ltd.

Sammut, R.G. (1997). Psychiatric nurses' satisfaction: The effect of closure of a hospital. Journal of Advanced Nursing, 26, 20-24. http://dx.doi.org/10.1046/ j.1365-2648.1997.1997026020.x, PMid:9231273

Schaufeli, W.B., \& Bakker, A.B. (2001). Werk en welbevinden: Naar een positieve benadering in de Arbeids - en Gezondheidspsychologie [Work and well-being: Towards a positive approach in occupational health psychology]. Gedrag \& Organisatie, 14, 229-253.

Schaufeli, W.B., \& Bakker, A.B. (2004). Job demands, job resources and their relationship with burnout and engagement: A multi-sample study. Journal of Organizational Behavior, 25, 293-315. http://dx.doi.org/10.1002/job.248

Schaufeli, W.B., Bakker, A.B., \& Salanova, M. (2006). The measurement of work engagement with a short questionnaire: A cross-national study. Educational and Psychological Measurment, 66(4), 701-716. http://dx.doi. org/10.1177/0013164405282471

Schaufeli, W.B., \& Salanova, M. (2007). Work engagement: An emerging psychological concept and its implications for organizations. In S.W. Gilliland, D.D. Steiner \& D.P. Skarlicki (Eds.), Research in social issues in management, (pp. 135-177). Information Age Publishers, Greenwich, CT.

Schaufeli, W.B., Salanova, M., Gonza'lez-Roma', V., \& Bakker, A.B. (2002) The measurement of engagement and burnout and: a confirmative The measurement of engagement and burnout and: a confirmative
analytic approach. Journal of Happiness Studies, 3, 71-92. http://dx.doi. analytic approach. Journal of

Schaufeli, W.B., Taris, T.W., Le Blanc, P., Peeters, M., Bakker, A.B., \& De Jonge, J. (2001). Maakt arbeid gezond? Op zoek naar de bevlogen werknemer [Does work make happy? In search of the engaged worker], De Psycholoog, 36, 422-428.

Schaufeli, W.B., Taris, T.W., \& Van Rhenen, W. (2008). Workaholism, burnout, and work engagement: Three of a kind or three different kinds of employee wellbeing? Applied Psychology, 57(2), 173-203. http://dx.doi.org/10.1111/j.14640597.2007.00285.x

Semmer, N.K., Zapf, D., \& Greif, S. (1996). Shared job strain: a new approach for assessing the validity of job stress measurements. Journal of Occupational and Organizational Psychology, 69, 293-311. http://dx doi. org/10.1111/j.2044-8325.1996.tb00616.x
Sharpley, C.F., Bitsika, V., \& Efremidis, B. (1997). Influence of gender, parental health and perceived expertise of assistance upon stress, anxiety and depression among parents of children with autism. Journal of Intellectual and Developmental parents of children with autism. Journal of Intellectual and Develo
Disability, 22, 19-28. http://dx.doi.org/10.1080/13668259700033261

Smyth, R. (2009). Depression in physical illness. The Journal of the Royal College of Physicians of Edinburgh, 39, 337-42. http://dx.doi.org/10.4997/JRCPE.2009.411, PMid:21152476

Spector, P.E. (1992). A consideration of the validity and meaning of self-report measures of job conditions. In C.L. Cooper \& I.T. Robertson (Eds.), International Review of Industrial and Organizational Psychology (vol. 7, pp. 123-151). Chichester: Wiley.

SPSS Inc. (2008). SPSS 16.0 for Windows. Chicago, IL: SPSS Inc.

Stein, D.J., Seedat, S., Herman, A., Moomal, H., Heeringa, S.G., Kessler, R.C., \& Williams, D.R. (2008). Lifetime prevalence of psychiatric disorders in South Africa. The British Journal of Psychiatry, 192(2), 112-117. http://dx.doi.org/10.1192/bjp.bp.106.029280 PMid:18245026, PMCid:2718689

Steyn, H.S. (2000). Practical significance of the difference in means. Journal of Industrial Psychology, 26(3), 1-3.

Struwig, F.W., \& Stead, G.B. (2001). Planning, designing and reporting research. South Africa: Pearson Education South Africa.

Sullivan, J. (2005). Promoting health and productivity for depressed patients in the workplace. Journal of Managed Care Pharmacy, 11(3), 12-15.

Tabachnick, B.G., \& Fidell, L.S. (2001). Using multivariate statistics. Boston: Allyn and Bacon.

Takai, M., Takahashi, M., Iwamitsu, Y., Ando, N., Okazaki, S., Nakajima et al. (2009). The experience of burnout among home caregivers of patients with dementia: Relations to depression and quality of life. Archives of Gerontology and Geriatrics, 49(1), 1-5. http://dx.doi.org/10.1016/j.archger.2008.07.002, PMid:18703239

Tomlinson, M., Grimsrud, A.T., Stein, D.J., Williams, D.R., \& Myer, L. (2009). The epidemiology of major depression in South Africa: Results from the South African Stress and Health study. South African Medical Journal, 99(5), 367-373.

Toppinen-Tanner, S., Ahola, K., Koskinen, A., \& Väänänen, A. (2009). Burnout predicts hospitalization for mental and cardiovascular disorders: 10-year prospective hospitalization for mental and cardiovascular disorders: 10-year prospective
results from industrial sector. Stress and Health, 25(5), 287-296. http://dx.doi. results from industrial
org/10.1002/smi.1282

Trochim, W., \& Donnelly, J. P. (2007). The research methods knowledge base. (3rd edn.). Mason, $\mathrm{OH}$ : Thomson Publishing.

Wells, K., Stewart, A., Hayes, R., Burnam, M., Rogers, W., Daniels, M. et al. (1989). The functioning and well-being of depressed patients. Journal of the American Medical Association, 262(7), 914-919. http://dx.doi.org/10.1001/ jama.1989.03430070062031

Werngren-Elgström, M., Dehlin, O., \& Iwarsson, S. (2003). Aspects of quality of life in persons with prelingual deafness using sign language: subjective wellbeing ill-health symptoms, depression and insomnia. Archives of Gerontology and Geriatrics, 37, 13-24. http://dx.doi.org/10.1016/S0167-4943(03)00003-7

WHO International Consortium in Psychiatric Epidemiology. (2000). Cross-national comparisons of the prevalences and correlates of mental disorders. Bulletin of the World Health Organisation, 78(4), 413-26.

Williamson, J. (2008). Depression. Phi Kappa Phi Forum, 88(1), 18-24.

World Health Organisation. (2001). Mental health around the world: Stop exclusion - dare to care. Retrieved July 08, 2010 from: http://www.who.int/world-healthday/previous/2001/files/whd2001_dare_to_care_en.pdf

World Health Organidation. (2010). Depression. Retrieved April 07, 2010, from: http:// www.who.int/mental_health/management/depression/definition/en/ 